\title{
LETTER
}

\section{Carbonate equilibria and the phase rule}

In this work the conditions required for the presence of two solid phases in equilibrium with a solution are discussed with special reference to the co-existence of magnesium calcites and dolomite in seawater. The criterion is determined in terms of the phase rule and of the solid-seawater ratio.

In this work the conditions required for the presence of two solid phases in equilibrium with a solution are discussed with special reference to the co-existence of magnesium calcites and dolomite in seawater. The criterion is determined in terms of the phase rule and of the solid-seawater ratio.

\section{INTRODUCTION}

In this work the qualitative features which may lead to the existence of only one or of two solid carbonate phases in contact with seawater are discussed. The discussion is based upon the phase rule and the relative amounts of seawater and solid.

It is generally accepted that dolomite is the most stable phase when calcium and magnesium are present concurrently with carbonate in solution but that the kinetics of dolomite formation are so slow that it appears only in old geological fluids. For a long time then one accepted a scale in which the solubility of the solids, inorganic and authigenic, which one found in seawater increased in the order pure calcite - low magnesium calcite - aragonite high magnesium calcite, if dolomite only present in contact with old pore waters of sediments was not considered.

More recently the concept was introduced that the phase at equilibrium with seawater was actually a magnesium-calcite possibly containing a five mole-percent magnesium rather than a pure calcite (e.g., Wollast and ReINHARD-DERIE, 1977). Aragonite, which appears when the molal ratio $\mathrm{Mg} / \mathrm{Ca}$ in the water is greater than four has been attributed to kinetic factors.

In older pore waters one finds dolomite and low magnesium calcite and it is the presence of these two concurrent phases which will be explained.

\section{Phase Rule and the $\mathrm{CO}_{2}$ System}

Consider the case of four components; $\mathrm{H}_{2} \mathrm{O}$,
$\mathrm{CO}_{2}, \mathrm{MgO}$ and $\mathrm{CaO}$. According to the phase rule

$$
f=c-p+2
$$

where $f$ is the number of degrees of freedom, $c$ is that of independent components, and $p$ is the number of phases.

If we fix the temperature and the pressure and, as $\mathrm{c}=4$ if a $\mathrm{CO}_{2}$ gas phase is present and at equilibrium with the solution $\left(\mathrm{pCO}_{2}\right.$ fixed), the maximum number of phases that can coexist at equilibrium is

$$
\mathrm{p}=\mathrm{c}=4
$$

In this expression the term 2 was dropped from equation (1) because $P$ and $T$ were fixed and $f$ was set equal to zero because we are seeking the maximum number of phases which, of course, uses up all the degrees of freedom.

One phase is given by the seawater and another by the $\mathrm{CO}_{2}$ gas. Thus, a maximum of two solid phases can exist at equilibrium with the seawater of which only one can be a solid solution while the other must be a pure compound. Otherwise, with two solid solutions at equilibrium with each other the chemical potentials of calcium, magnesium, and carbonate would have to be the same even if the ratios of calcium to magnesium differed. The case of dolomite is different because it is a compound so that one does not need to be concerned with the chemical potentials of individual ions.

Furthermore, if the composition of a solid solution at equilibrium with a liquid solution was fixed this would fix the composition of the liquid solution due to the equality of the chemical potentials in the two phases. Then, with $f=4-3+2=3$ all the degrees of feedom would be used at a given set $\mathrm{T}, \mathrm{P}$, solid solution of fixed composition, and a second solid solution could not exist.

The argument above does not mean that two 
solid phases must exist and the answer must be provided by nature. There could be, for example, one solid phase if some other property of the system, such as the $\mathrm{pH}$, was fixed. In this case

$$
\mathrm{f}=4-3+2=3
$$

with $\mathrm{P}, \mathrm{T}$, and $\mathrm{pH}$ fixed while in the case of two solids

$$
f=4-4+2=2
$$

It must be remembered that equations (3) and (4) correspond to $\mathrm{pCO}_{2}$ fixed. In old pore waters it is more likely that the $\mathrm{pH}$ is stated by $\mathrm{SiO}_{2}$ and aluminium silicates (CULBERSON et al., 1975) and that $\mathrm{pCO}_{2}$ fluctuates due to bacterial activity. Then, we have equation (4) with $\mathrm{pCO}_{2}=$ constant replaced by $\mathrm{pH}=$ constant and two solids such as dolomite and a magnesium calcite can co-exist in principle. Another condition is required, however, because, as was shown by Stumm and Morgan (1970) pure calcite and dolomite as an example can only coexist when

$$
\frac{\mathrm{Ca}^{2+}}{\mathrm{Mg}^{2+}}=\frac{\left.\mathrm{K}^{2} \text { (calcite }\right)}{\mathrm{K}(\text { dolomite })}
$$

where $\mathrm{K}$ represents the thermodynamic solubility product of the species in parentheses. This can only happen when the amounts of calcium and magnesium in solution are small realtive to those

\section{REFERENCES}

Culberson, C. H., Pytkowicz, R. M., and E. L. ATLAS (1975) Hydrogen ion exchange on amorphous silica in seawater. Mar. Chem. 3, 43-54.

STUMM, W. and J. J. MORGAN (1970) Aquatic chemistry. Wiley-Interscience, New York.

WEYL, P. K. (1961) The carbonate saturometer. $J$. in the solids so that the dissolution of the solids can lead to equation (5). This condition can be met in compact submarine sediments but not in contact with open oceanic waters.

In conclusion, dolomite and a given lowmagnesium calcite can only co-exist where the solid/seawater ratio is large and where only one pertinent variable of the $\mathrm{CO}_{2}$ system, such as the $\mathrm{pH}$, is fixed. These conditions are met in old sediments and their pore water as well as the time scale for the slow diagenesis of high magnesium calcites to the above two phases. In open oceanic waters the suspended or settled carbonate solids cannot control the water composition for condition (5) to be obeyed.

In the laboratory one may have a large solid/seawater ratio in a saturometer experiment (WEYL, 1961) and a fixed solid composition but the time scale for the diagenetic alteration of high-magnesium calcite to low-magnesium calcite and dolomite is not available.

\section{ROLAND WOLLAST ${ }^{1}$ and RICARDO M. PYTKOWICZ ${ }^{2}$}

\author{
Department of Oceanography, \\ Free University of Brussels, \\ Brussels, Belgium ${ }^{1}$ and \\ School of Oceanography, \\ Oregon State University, \\ Corvallis, Oregon, U.S.A. ${ }^{2}$
}

(Received March 18, 1978)
Geol. 69, 32-44.

WOLLAST, R., and D. REINHARD-DERIE (1977) (Equilibrium and mechanisms of dissolution of $\mathrm{Mg}$.-calcites. In The fate of fossil fuel $\mathrm{CO}_{2}$ in the oceans, N. R. ANDERSEN and A. MAlAHOFF, eds. Plenum Press, New Yor, 479-496. 